\title{
AOS VENCIDOS, A FLORESTA - ALEXANDRA LUCAS COELHO LENDO MÁRIO DE ANDRADE E MACHADO DE ASSIS
}

\section{ANDRÉ CORRÊA DE SÁ}

University of California, Santa Barbara

Santa Bárbara, Califórnia, Estados Unidos

Resumo: Este ensaio discute as imagens do Brasil que Alexandra Lucas Coelho nos oferece em Vai, Brasil (2013), Deus-dará (2016) e A nossa alegria chegou (2018), mostrando de que maneira se relacionam com as imagens do Brasil disponibilizadas por Mário de Andrade e por Machado de Assis. Propondo que, a esse respeito, Vai, Brasil está mais próximo de Machado de Assis e Deus-dará e A nossa alegria chegou estão mais próximos de Mário de Andrade, argumentarei que esse posicionamento, talvez de modo paradoxal, levou a que Lucas Coelho, em prol de uma descrição transatlântica e pós-colonial das interações luso-afro-brasileiras, nos ofereça uma versão menos ecológica do Brasil.

Palavras-chave: Alexandra Lucas Coelho; Machado de Assis; Mário de Andrade.

\section{TO THE LOSERS, THE FOREST - ALEXANDRA LUCAS COELHO READING MÁRIO DE ANDRADE AND MACHADO DE ASSIS}

Abstract: This essay debates the images of Brazil provided by Alexandra Lucas Coelho in her novels, Vai, Brasil (2013), Deus-dará (2016) and A nossa alegria chegou (2018), by showing how they relate to the images of Brazil in the works of Mário de Andrade and Machado de Assis. In this sense, I depart from the suggestion that Vai, Brasil is more closely related to Machado de Assis, while Deus-dará and A nossa alegria chegou to Mário de Andrade, to argue that this shift, maybe paradoxically, led Lucas Coelho to develop a transatlantic and postcolonial description of Luso-Afro-Brazilian interactions at the expense of a version of Brazil that appears to be less ecological.

Keywords: Alexandra Lucas Coelho; Machado de Assis; Mário de Andrade. 
Carlos, devote-se ao Brasil, junto comigo.

Mário de Andrade

Outros leram da vida um capitulo, tu leste o livro inteiro. Carlos Drummond de Andrade

U

ma das coisas que frequentemente se repete sobre o Brasil é que o Brasil não é um país para principiantes. A fórmula originalmente atribuída a Tom Jobim tem um significado ainda mais profundo na presente Era das Alterações Climáticas, como se vê pelas questões recentemente suscitadas pela gestão da floresta amazônica. O sentido de principiante que está aqui em causa nem sempre é fácil de explicar a um estrangeiro: regra geral, refere-se ao fato de possuírem o Brasil e os brasileiros um conjunto copioso de particularidades tão unicamente brasileiras que o neófito, sobretudo o português que se muda de bom grado para São Paulo ou para o Rio de Janeiro, a princípio tem certa dificuldade em compreender. Essa tese favorita, e a série de proposições que origina, parecem-me estar substancialmente presentes na trilogia de Alexandra Lucas Coelho composta por Vai, Brasil (2013), Deus-dará (2016) e A nossa alegria chegou (2018) - que, para efeitos deste ensaio, considero constituir um tríptico em torno do Brasil, país que Lucas Coelho, enquanto por lá viveu, procurou conhecer em profundidade.

Vai, Brasil é uma antologia de crônicas sobre a experiência brasileira da autora, primeiramente publicadas na imprensa portuguesa. É basicamente um livro sobre as dores de crescimento de um país multiforme como o Brasil, de história e formação muito complexas. Deus-dará pode descrever-se, muito aproximadamente, como um roteiro romanceado do Rio de Janeiro, protagonizado por cinco brasileiros e dois portugueses, que acompanhamos em sete dias ao longo de três anos. Consumando a troca dos velhos formalismos lusitanos pelo idioleto vibrante da Cidade Maravilhosa numa dramatização de todos os discursos possíveis sobre o Rio de Janeiro, Deusdará vai de um relato detalhado do quotidiano carioca a um ensaio históricosocio-linguístico sobre as idiossincrasias da cidade, as raízes da brasilidade e o conformismo frouxo e provinciano dos portugueses perante as ladainhas com que se papagueiam entre si uma história imperial de má memória.

Este romance transatlântico, argumentará Lucas Coelho, é a ambiciosa peça central das suas reflexões, o tronco de onde se ramificam outros livros sobre o Brasil. Deus-dará já não é um livro sobre as dores de crescimento de um país latino-americano, tema do livro anterior. Dirigido aos brasileiros, o 
romance trata das dificuldades de ser adulto num mundo darwiniano, acidentado e injusto e extremamente cruel para grande parte da humanidade. Dirigido aos portugueses, o romance faz coro com uma bibliografia pós-colonial e descolonial cada vez mais extensa para nos ajudar a reconhecer com frontalidade as nossas responsabilidades no mundo que sobreveio ao fim dos impérios.

Em muitos sentidos, graças à sua ambição transatlântica e à sua capacidade de quebrar barreiras epistemológicas de toda a espécie, Deusdará é um livro ímpar tanto nas literaturas contemporâneas em língua portuguesa como na história das relações literárias luso-afro-brasileiras. A nossa alegria chegou, por sua vez, pode sintetizar-se como uma espécie de límpida fábula juvenil dirigida sobre a experiência histórica da Modernidade, cujo ethos filistino tem puxado o tapete debaixo dos pés de milhões dos nossos companheiros de mundo. Para conferir intensidade didática e alcance global à mensagem, o Brasil referencial dos livros anteriores foi neste livro traduzido numa espécie de Avatar - que a autora nomeou por "Alendabar" posto ao serviço de uma propedêutica ética, cultural e ambiental de ação global, na qual a geografia, a fauna e a flora foram estetizadas nos termos de um ritual contracultural.

Correndo o risco de reduzir a uma só perspetiva livros que evidentemente se abrem a múltiplos modos de ler, este ensaio tem um objetivo muito específico: proponho traçar um contraste entre as imagens do "Brasil" que obtemos em Vai, Brasil, Deus-dará e A nossa alegria chegou, procurando relacioná-las com o "Brasil" de alguns dos livros consensualmente mais importantes da literatura brasileira. O meu objetivo é mostrar em que sentido o "Brasil" confessional e psicológico dos livros de Alexandra Lucas Coelho reflete o "Brasil" de livros como Dom Casmurro e Macunaíma (e, por associação, de livros como Iracema), conjurando desse modo uma reflexão sobre certos usos da noção de "brasilidade" e sobre certas consequências desses usos. Por uma questão heurística, vou limitarme, mais precisamente, a abordar os casos de Machado de Assis e do primeiro movimento modernista que, sob a liderança intelectual de Mário de Andrade, foi "o criador de um estado-de espírito revolucionário e de um sentimento de arrebentação." (ANDRADE, 1974, p. 241). Muito livremente inspirado no método comparativo que Antonio Candido utiliza em Formação da literatura brasileira, proponho que olhemos para os livros desses escritores não como os antecessores genealógicos ou os referenciais de valor 
de Vai, Brasil, Deus-dará e A nossa alegria chegou, mas como o telos em função do qual Lucas Coelho dá a conhecer o Brasil ao leitor contemporâneo.

Para introduzir os pontos centrais deste ensaio, permitam-me resumilos por meio de uma pequena parábola envolvendo dois intelectuais de um planeta ficcional e ecologicamente débil, ainda que extenso e rico, cujos habitantes regularmente conversam sobre a crise ambiental que atravessam e sobre como essa crise pode interferir de forma irreversível no quotidiano da comunidade.

Imaginem que o escritor modernista $M$ de $A 1$ é um desses cidadãos interventivos que participam ativamente em debates polêmicos sobre tópicos emergentes como a poluição, as saudades da paisagem intocada ou a maneira de recomeçar o mundo depois do apocalipse. Tal como os colegas da mesa modernista, $M$ de Al define-se como um ecologista profundo, adepto da Hipótese de Gaia de James Lovelock, segundo a qual o planeta consiste em um sistema homeostático integral, denominado "Gaia", reflexo da interdependência que se estabelece entre os seres vivos e o ambiente inorgânico. $\mathrm{M}$ de Al acredita que a ameaça que paira sobre Gaia resulta do fato de ter sido o sistema originário vítima de uma invasão por hordas de colonos que hostilizaram os habitantes nativos e corromperam a paisagem de autenticidade e os costumes indígenas, alterando irreversivelmente a matriz de sustentabilidade que até aí pautava a relação dos homens com a terra habitada. Como solução, $\mathrm{M}$ de $\mathrm{Al}$ propõe que a salvação do planeta depende do esforço de virar as costas ao invasor, cinzelando uma tradição privada com base não numa atitude nostálgica face ao bom selvagem, mas na exposição radical à mistura de identidades, línguas e retóricas disponíveis tanto no planeta como no exterior.

Enquanto $\mathrm{M}$ de $\mathrm{Al}$ é fruto do alto rendimento estético e político de uma ideia de nação, $\mathrm{M}$ de A2, outro dos intervenientes dos debates, prefere ver as alterações climáticas como um problema que pede que se experimentem soluções e não como pretexto para uma competição especulativa entre perspectivas teóricas antigas e modernas. Curiosamente, apesar de ser estimado por um público muito considerável, a verdade é que têm gorado todas as tentativas de popularizar numa tese compreensiva os esquemas e as ideias do seu pensamento. O certo é que, em questões de política ambiental, $\mathrm{M}$ de A2 tem uma objeção clara aos paradigmas ecológicos que solicitam o 
aparecimento de consciências irrestritamente devotadas à substância nacional. Talvez pelo fato de não lhe ter a ordem cósmica destinado o berço de ouro dos modernistas, o argumento romântico-modernista sobre a relação entre a saúde do planeta e a poética que o pode exprimir autenticamente não lhe parece assim tão óbvio. $\mathrm{M}$ de A2 pensa que os dilemas ecológicos do planeta não se resolvem com visões unificadoras, muito menos com compromissos de índole utopista, adornados com cocar, papagaio e palmeira. Mas ter dúvidas em relação às metáforas e ao fetichismo gramatical dos modernistas não significa que $M$ de A2 não se preocupa com o equilíbrio ecológico do planeta. O que ele não está disposto a considerar é que o ajuste das condições ambientais passa necessariamente pelo tipo de compatibilização de uma identidade anárquica e primitivista com o cosmopolitismo esclarecido que os artigos de fé da teoria modernista solicitam ao intelectual comprometido com o país e o povo.

$M$ de $A 2$ pensa que a tentativa modernista de responder à crise ecológica com jogos de linguagem em torno das Raízes e da Verdade da Comunidade não deixa espaço suficiente para a visão pragmática da realidade que dará acesso à liberdade por meio de uma redescrição contínua das maneiras de falar do que nos rodeia. Nutrindo pouco apreço pelas etnologias um pouco confusas do grupo de $\mathrm{M}$ de $\mathrm{Al}$, as recomendações de $\mathrm{M}$ de A2 em relação aos problemas ecológicos coincidem, em grande medida, com a estratégia ficcional dos livros que escreve. Isto é: ele pensa que a nossa relação com o meio ambiente depende mais do esforço de ouvir todas as vozes possíveis entre os membros da comunidade (ainda que a conversa se torne ambígua, cômica e sombria ao mesmo tempo) do que pela tentativa (tipicamente religiosa) de convencer os nossos companheiros a confiar cegamente em metáforas de criação e salvação, por muito úteis que sejam para o nosso amor-próprio. Daí que $\mathrm{M}$ de $\mathrm{Al}$, que tinha aprendido com os românticos a desconfiar de poemas e romances sem pontos de referência locais como palmeiras e sabiás, tenha prontamente acusado M de A2 de estar exilado de uma forma de vida cultural ecologicamente "nacional".

Tendo em vista essas discordâncias de base em relação a crenças privadas e políticas públicas, é inevitável que os dois não sejam os melhores amigos. No que se segue, irei transpor os termos desta analogia até conseguir usá-la como eixo de uma possível distinção entre Mário de Andrade ( $M$ de A1) e Machado de Assis (M de A2), que seja também uma distinção entre os Brasis que, diante dos olhos do leitor, se espraiam de Vai, Brasil a Deus-dará e a $A$ nossa alegria chegou numa forma aparentemente contínua. Invertendo, 
como explicarei dentro em pouco, a premissa teleológica da Formação da literatura brasileira de Antonio Candido, defenderei que uma visão machadiana, parca em "cor local", mas abundante na noção de que as perspetivas de cada um são meramente as perspetivas de cada um, pode hoje em dia servir mais eficazmente as populações desfavorecidas do Brasil, cuja voz Alexandra Lucas Coelho tanto quer trazer para o centro dos seus livros.

Se concordarmos com a interpretação retrospectiva defendida por Antonio Candido em Formação da literatura brasileira, que ganhou entre os brasilianistas claro ascendente sobre as interpretações alternativas de Afrânio Coutinho e Haroldo de Campos, o limiar a partir do qual os destinos culturais do Brasil e de Portugal são ontologicamente apartados pode ser mais ou menos definido como o espaço político, econômico e social que se desenvolve entre o Segundo Reinado e a Proclamação da República. Ou, se preferirmos, como o espaço literário que se desenvolve entre os poemas indianistas de Gonçalves Dias e a autonomia heroica dos Modernistas de 1922. A independência política, como já Machado advertira no célebre "Notícia da atual literatura brasileira. Instinto de nacionalidade", é vista como antecedendo por uma geração ou mais a independência literária, e as manifestações de independência cultural como o momento áureo da sequência de eventos históricos que permitiu ao povo brasileiro entrar em contato consigo mesmo.

José de Alencar e, muito particularmente, Machado de Assis, os dois escritores maiores do Brasil oitocentista, foram as primeiras vítimas da estratégia essencialista de um crítico tão dominante como Antonio Candido, o qual, decidido a alinhar a história da formação da literatura brasileira com a história política do Brasil, concatenou com veemência os diversos momentos de uma narrativa épica e teleológica que postulava que, em questões de supremacia identitária, atitude anticolonialista e sistematização do imaginário nacional, Alencar necessariamente não tinha sido tão bemsucedido quanto Machado, da mesma maneira que Machado necessariamente não tinha sido tão bem-sucedido quanto os modernistas. Em relação a Alencar, que abriu as portas da sua imaginação ao temário da floresta tropical com uma intimidade que os árcades não tinham literariamente experimentado, os discípulos de Candido têm repetidamente sugerido que os índios de Iracema não são como os índios realmente eram, e por isso não 
funcionavam suficientemente bem como elo de ligação entre os seus concidadãos.

Em relação a Machado, embora Memórias póstumas de Brás Cubas, Dom Casmurro e Memorial de Aires permaneçam largamente irredutíveis a esquemas teleológicos e seja possível fazer coisas totalmente contrastantes com eles, críticos como Afrânio Coutinho, Antonio Candido e Roberto Schwarz têm ocupado as últimas décadas a corrigir as interpretações dos críticos anteriores e a tentar convencer-nos, cada qual do seu jeito, de que a situação de Machado perante a tradição literária deve ser considerada secundária em relação às suas responsabilidades perante a nação brasileira e a causa brasilianista. Por isso esses críticos têm elencado uma série de razões pelas quais é importante considerarmos que o maior escritor brasileiro de todos os tempos é também a culminação do processo de formação da literatura brasileira e insistido que obras-primas como Memórias póstumas de Brás Cubras e Dom Casmurro são dois dos elos mais brilhantes do gênio nacional que alimenta o espírito de todos os livros que entre $A$ Confederação dos Tamoios e Macunaíma (1988) representam a grande antinomia que separa a literatura brasileira da literatura portuguesa que a precedeu.

Harmonizado nos seus diversos aspectos políticos, sociais e retóricos, e meticulosamente inserido, tal como faz Candido, no mapa formativo da literatura brasileira enquanto tal, esse espaço literário - de costas voltadas para o legado colonialista português e circunscrito a movimentos autotélicos - é-nos apresentado como o momento de estabilização e de sublimação dos traumas passados que preparou adequadamente o terreno para a maturação da importante noção de "antropofagia", cunhada por Oswald de Andrade em 1928.

No âmbito do movimento modernista de vinte e dois, o Manifesto Antropófago (1976) traduz um significativo passo adicional em relação à estética do Pau-Brasil exaltada pelo mesmo Oswald um par de anos antes. "No país da cobra grande" - declara profeticamente Oswald - a única lei que impera é a "lei do antropófago". Com o Manifesto Antropófago completa-se, enfim, o projeto nativista encetado pelos românticos mais de sessenta anos antes e subscrito com novo vigor pelos modernistas. Brilhantemente exemplificado pelo Macunaíma, o refrão antropofágico é ainda hoje o maior símbolo da consciência moral brasileira tipicamente vigente. 
Geralmente considera-se que Mário de Andrade, Tarsila do Amaral, Oswald de Andrade, Paulo Prado, Graça Aranha, Plínio Salgado, Raul Bopp, Gilberto Freyre, Graciliano Ramos, José Lins do Rego, Portinari etc. foram companheiros numa luta comum pela peculiar emancipação cultural que se manifestou nos termos da novidade da linguagem e das práticas estéticas do Modernismo. Costuma-se descrever essas pessoas explicando que foram capazes de desenvolver pela primeira vez os instrumentos adequados (as literaturas, as músicas, as artes plásticas) para entrar em contato com, e exprimir religiosamente, a essência original do ser brasileiro.

Os modernistas tinham em comum com os românticos a crença no poder expansivo das metáforas, mas viam-se como tendo inventado um vocabulário inédito e poderoso que atrapalhava, como nunca ninguém até aí tinha conseguido, os resquícios perniciosos da subserviência cultural da inteligência brasileira. Controversos, estridentes e persuasivos, os livros, os quadros e as músicas modernistas rapidamente se assumiram como um epítome da experiência vital nacional. Lado a lado com uma gama de poemas e romances socialmente úteis e particularmente reconfortantes para o amorpróprio dos brasileiros - de Iracema ao Manifesto Antropófago, do Macunaíma e Cobra Norato a Menino de Engenho e Vidas Secas - surgiram ensaios igualmente poderosos - Retrato do Brasil, de Paulo Prado, Casagrande et senzala, de Freyre, Raízes do Brasil, de Sérgio Buarque, e Formação do Brasil contemporâneo, de Caio Prado Jr. - que rasgaram os horizontes das grandes construções interpretativas do caráter nacional. Até os nossos dias, de resto, é pacífico sustentar que a empatia com que o modernismo foi falando dos brasileiros aos brasileiros, por meio de constantes e sutis mudanças de pele (MARTINS, 2002, p. 197), constitui ainda a base seminal de uma linhagem de livros tendencialmente interpretados quer como breviários íntimos da personalidade brasileira, quer como instrumentos empenhados na transformação social.

Todavia, vale lembrar que, independentemente da diferença entre os modelos literários e dialéticos preferidos, o radicalismo da exclusão do português e os modos de reencenar o imaginário indígena, a noção do que conta como "brasileiro" para os modernistas está inteiramente conotada com a noção do que conta como "brasileiro" para românticos como Gonçalves Dias ou José de Alencar. Mesmo que o ethos medieval que ainda impregnava as obras dos românticos lhe parecesse obsoleto, as distinções que articulavam bastante rudimentares e os índios demasiado estilizados, é preciso sublinhar que a ênfase nacional-indianista levada a cabo em livros 
como Os Timbiras e Iracema permitiu a Mário de Andrade poupar um tempo precioso na sua demanda por um pensamento e uma forma genuinamente brasileiros.

Em boa verdade, Gonçalves Dias e Alencar, Oswald e Mário de Andrade estão unidos pela mesma pretensão autonomista e revolucionária de projetar a forma do Brasil para lá das velhas doutrinas coloniais e mostrar que a arte deve estar essencialmente subordinada à expressão dessa fisionomia intrínseca. É por isso que, mesmo diferindo no modo de expressão literária, os empreendimentos para realizar o "levantamento do Brasil" e o nascimento do "herói de nossa gente" com base nos lendários indígenas, nas tradições folclóricas e na aura de promessa da floresta são, em aspetos decisivos, convergentes (apesar de Macunaíma ser mobilizado pelo desejo de emancipação do desajustado idealismo "luso-tupi" dos amores maviosos de Iracema e Martim no sentido de uma abertura para a alteridade, o que explica a sua inclemência no que toca às visões de mundo feudalistas a que o indianismo de Alencar se acomoda).

Porém, no que concerne ao que tentaram fazer afetivamente pelas autoimagens do Brasil e do povo brasileiro, não temos maneira de diferenciar José de Alencar de Gonçalves Dias, nem Gonçalves Dias e Alencar de Oswald e Mário de Andrade. Em Dialética da colonização, Alfredo Bosi (2002, p. 177) detecta que o esquema indianista de Alencar pressupõe o sacrifício do índio ao modelo heroico do colonizador, numa combinação idealista que tem o efeito de purificar a história trágica da conquista nos termos de uma dinâmica da revelação mútua que irmana o invasor ao bom selvagem da floresta. Ora, se Macunaíma, com o seu sentido contraditório da existência, por um lado evidentemente não é o idealista Peri, por outro, não deixa de prolongar os esquemas míticos que parafraseiam a invasão da floresta ancestral na instância de devoração cultural e "consciência participante" que Oswald invoca no Manifesto Antropófago.

Não há entre eles nenhum desacordo político substancial. O fato de os índios e as florestas primordiais de Gonçalves Dias e de Alencar, esboçados em alegoria rousseauniana, embora de sabor anacrônico, serem, em termos de fundação da identidade própria do brasileiro, tão índios e tão florestas como os índios e as florestas "descolonizadas" de Oswald e de Mário de Andrade, esboçados em alegoria canibal, anula grande parte da diferença entre os românticos e os modernistas, subsumindo-a na poética de construção do Brasil cuja responsabilidade ambos voluntariamente partilham. 
Pesem as polêmicas que os separam, é na verdade encorajado pelo exemplo de Alencar que Macunaíma atualiza a resposta aos modelos europeus que faz justiça às autoimagens nacionais. Ainda que introduza critérios distintos, o seu ritual nativista - que Oswald, à revelia de Mário, elevou unilateralmente a arquétipo tutelar do movimento antropofágico está possuído pelo mesmo desejo de descobrir, e depois custodiar, um jardim arrojado de fusão e experimentalismo cultural que salvaguarde o sentimento nacional sob uma nova divisa cultural. Isso quer dizer que, apesar da controvérsia que se instala entre eles, como bem perceberam autores como Aparecida Ribeiro (1995, p. 1024) e Haroldo de Campos (1992, p. 129-130), o argumento nacionalista que ambos nos oferecem é idêntico.

Se a maneira como cortam caminho através da carta de Pêro Vaz com vistas a exorcizar os efeitos da colonização num novo direito das gentes e da terra se realiza por meio de paisagens, perplexidades, hábitos retóricos e truques linguísticos muito distintos, tanto Iracema como Macunaíma têm em comum o fato de enfrentarem com dados etnográficos a tese machadiana de que uma utopia identitária erigida sobre a excecionalidade do que somos e sobre a nossa comunhão com o solo, para além de serem irrelevantes para o trabalho do escritor, só nos levam a becos sem saída.

Ainda hoje, as diferentes ênfases que os críticos literários encontram na obra de Machado de Assis têm como centro de gravidade as reflexões em torno do fino humor, da ironia e das qualidades realistas de livros como Memórias póstumas de Brás Cubas e Dom Casmurro. Atualmente, a interpretação dominante na academia brasileira talvez seja a que Roberto Schwarz, aperfeiçoando o repertório marxista de Candido, começou a traçar em Ao vencedor as batatas (1977). Foi precisamente o destaque da dimensão representativa de Machado que lhe permitiu completar o processo de transferência do escritor "de exceção, anacrônico e excêntrico" (GUIMARÃES, 2017, p. 64) que sobreveio da receção inicial e da mitificação nacional para a confortável cobertura no edifício funcional da cultura pátria onde presentemente se encontra.

Até aí, a relação de Machado com o país - mesmo com o país que o ergueu a patrono da literatura nacional - nunca fora consensual. Entre os coevos, as opiniões de Sílvio Romero, "quase sempre injustas e destrambelhadas", tiveram ao menos a virtude de situar Machado "no centro 
das atenções, de onde não saiu até hoje” (GUIMARÃES, 2017, p. 31 e p. 68). Araripe Jr. e José Veríssimo, que o admiravam, não pouparam esforços para enfatizar que Machado era "um escritor à parte" (GUIMARÃES, 2017, p. 50). Mais tarde, à medida que Machado, via Augusto Meyer, Lúcia Miguel Pereira e Astrojildo Pereira, foi sendo erguido a mito nacional durante o Estado Novo de Vargas, a polêmica persistia. Agripino Grieco, em polêmica contra Afrânio Coutinho e Augusto Meyer, sublinhara o caráter exógeno do humor típico de Machado. O próprio Mário de Andrade, em carta a Drummond, confidenciou que Macunaíma tinha o intuito de "tradicionalizar a orientação humorística brasileira representada por Machado na literatura de ordem artística” (ANDRADE, 2002, p. 277). Fato que não abonava a favor de Machado: enquanto conspiravam para demolir os atavismos da Academia, os modernistas - nas raras vezes em que se voltaram para Brás Cubas ou Dom Casmurro - sugeriram que o nosso interesse pelo "Sterne do Cais Pharoux" deveria limitar-se, e preferencialmente de longe, a absorver o virtuosismo técnico dos seus livros. Pensando que Machado de Assis se fez o mais perfeito exemplo de "arianização" e de "civilização da nossa gente" (ANDRADE, 1974, p. 104), Mário de Andrade pensava que as formas literárias de Machado, transplantadas sutilmente de paisagens europeias, traíam o projeto de formular o jargão apto a descrever em português brasileiro a doçura de uma tarde na rede, tomando água de coco. Se insistirmos em extrair dos seus livros as premissas que justificam a autonomia da cultura brasileira - alertava Mário - iremos descobrir-nos amargamente sós, sem o esplendor solidário dos retratos de grupo.

Respondendo ao desconforto manifestado pela hoste modernista, que não encontrava nos livros do acadêmico Machado de Assis a relação orgânica entre literatura e nacionalidade que já divisava no Aleijadinho e em Castro Alves e a que aspirava nos seus próprios livros, José Guilherme Merquior argumentou que a intrincada malha do humorismo machadiano, graças ao seu ímpeto carnavalesco, nos ajuda a abandonar "tanto as quimeras do idealismo quanto a prostração derrotista" (MERQUIOR, 1996, p. 251) que emana das existências pessimistas e melancólicas que povoam os seus romances. Dessa forma, o cinismo de Machado não deve ser interpretado como sintoma de autoindulgência perante os termos da sua própria narrativa de ascensão social na sociedade do Brasil novecentista, como reclamaram alguns espíritos equivocados, mas uma sóbria e bem-sucedida variante brasileira da "visão problematizadora" perante a qual responde a estética literária moderna. 
Enquanto tentarmos medir o nacionalismo de Machado, alega Merquior num eco de Roger Bastide, pela atmosfera localista de João do Rio ou Lima Barreto estaremos a compreendê-lo mal. Se insistirmos, à semelhança de Mário de Andrade, em generalizar a linha crítica de Sílvio Romero e rebaixar Machado pelo fato de os seus livros não terem a pretensão de desvelar o "ser representativo do Homo brasileiro" que contribua para cicatrizar as feridas da colonização com o retorno "matovirginal" a si mesmo, não seremos capazes de compreender o sentido do "nacionalismo interior" e a inconformação do criador de Capitu com os destinos do seu país.

A lucidez de Merquior, lembrando que a ficção de Machado não se limita a evocar a atmosfera pitoresca do Rio de Janeiro ou a dinâmica social da sua época, mas a universaliza, antecipa, de certa maneira, o comentário pragmático de Alfredo Bosi (2006), quando este, retomando e sistematizando as várias leituras de Brás Cubas, previne que irão inevitavelmente falhar todas as tentativas de sintetizar numa visão unificada livros tão multímodos como os de Machado (BOSI, 2006, p. 51). Ao passo que escritores como Mário defenderam justamente o papel instrumental da arte na ocupação pronominal da brasilidade, Machado leva-nos a pensar que a utilidade do escritor brasileiro não depende de se declarar a justa casus belli contra o putativo "inimigo" que afasta o povo de si mesmo, nem de colocar palavras como "nacionalismo" ou "regionalismo" sob a égide de uma nostalgia empírica por uma língua pátria. A única obrigação de um escritor brasileiro defende o Bruxo em "Instinto de nacionalidade" - é tentar encontrar na tradição ocidental uma cadeira que lhe sirva: a de "certo sentimento íntimo, que o torne homem do seu tempo e do seu país" (ASSIS, 2013, p. 430-431).

Merquior viu, muito corretamente, que quando Mário de Andrade procurava subsumir a obra de Machado de Assis no fervor modernista, não estava propriamente a fazer observações a respeito dos supostos pedantismos linguísticos e filosóficos do Mestre, mas a acusar o Bruxo do Cosme Velho de não ter sido capaz de se libertar das noções e vocabulários inculcados na sociedade brasileira do século XIX, que, cautelosamente, conciliava ideias liberais com práticas escravocratas. À semelhança do que aconteceu com muitos escritores do período modernista pós-antropofagia, Mário vivia atormentado com a necessidade de tornar compatíveis a matriz experimentalista do vanguardismo, apanágio do artista diletante, e a rotina social do intelectual engajado, empenhado em fazer com que o futuro do país seja melhor do que o passado. A este respeito, é preciso ainda sublinhar que o 
direito de declarar guerra a tropos precedentes que os modernistas viam como problemáticos inclui tanto uma objeção moral ao passado literário luso-brasileiro como a constituição de uma obrigação ao mesmo tempo transcendente e interna em relação à nação. Achando que não tinham muito a dizer ao país, enquanto território luso-afro-índio-caboclo partilhado, Mário de Andrade tentou persuadir-nos de que as palavras de Alencar e de Machado, ainda demasiado afrancesadas, não eram por si só capazes de alcançar as grandes e profundas extensões de terra roxa e outras terras onde o povo brasileiro teria de remodelar a "Inteligência nacional".

Ao combinar mitos, lendas e heranças de tradições diversas, Macunaíma oferece aos seus companheiros brasileiros precisamente aquilo que Iracema e Brás Cubas não foram capazes de oferecer de forma efetiva um conjunto de palavras e um estado de espírito ontologicamente "sacrificados" aos assuntos nacionais. Por isso a "fala impura" do "herói sem nenhum caráter" disponível-para-absorver-qualquer-caráter se revelou tão conciliada com os dilemas identitários que os artistas modernistas tinham de travar para que o Brasil finalmente despertasse do sono colonial e tomasse o lugar que era por direito o seu no concerto das nações. Percebendo que é a repetição da memória que interessa, e não a sua preservação, Mário forjou em Macunaíma a condição de possibilidade do "espírito religioso da vida" (ANDRADE, 2002, p. 48) que pregava como o paradigma maior da empresa fundacional da Alma Brasileira, tanto que argumentou a favor de uma distinção irrevogável entre o ceticismo eurocêntrico de Machado e a felicidade sensual e profética dos modernistas. $\mathrm{O}$ autor que se desdobrou em livros tão distintos quanto o iconoclasta Clã do Jabuti ou o erudito Ensaio sobre a música brasileira quis que todos os brasileiros se importassem com as mesmas coisas que os modernistas, e tinha a ambição de que as suas pesquisas literárias, etnomusicais e culturais fossem recebidas como recomendações políticas e institucionais relativas a um país tropical e póscolonial.

Em suma, Mário achava que Machado tinha de ser afastado não por pensar que Machado era uma fraude como escritor, mas por estar convicto de que a tradição literária que nos lega Memórias póstumas e Quincas Borba tem pouca utilidade para o projeto anticolonial da cultura brasileira que deve consubstanciar o papel do artista numa resposta concreta à realidade profunda do Brasil. Desgostoso, o autor de Pauliceia desvairada pensava que as formas de representação e os vocabulários do Bruxo não se mostravam capazes de enfrentar as realidades exclusivamente americanas da mesma 
maneira que o "riso claro dos modernos", nem de oferecer o tipo de terreno intermédio onde o mato virgem da terra brasilis e o pluralismo latente das realidades culturais, políticas e sociais brasileiras pudessem ser higienizados dos acanhados esconsos lusitanos e devidamente acomodados na narrativa comum de experimentação, pertencimento e esperança social com que os românticos tanto tinham sonhado.

Ora, todos esses momentos decisivos da história da literatura brasileira podem ser literalmente experimentados na trilogia de Alexandra Lucas Coelho, se bem que numa cronologia oblíqua e dissimulada. Obviamente, o clima espiritual que norteia Deus-dará deriva, em grande medida, do espírito bélico dos salões modernistas da década de 1920. Transpondo para as suas páginas o amalgamento de múltiplas tradições - típico da prática antropofágica -, Lucas Coelho confronta a língua doméstica dos portugueses com a língua carnívora dos brasileiros que já nasceram de costas voltadas para Portugal. Deus-dará identifica-se, por isso, como a transcrição portuguesa contemporânea da aventura modernista, ou seja, colocando-o de outra maneira, Deus-dará, interessado apenas no que não é dele, é, portanto, uma espécie de Macunaíma adaptado ao gosto do leitor português.

Já se sabe que assentar os pés no chão do Brasil e explicar aquilo que vê em redor não constitui tarefa para amadores. As várias interpretações do fenômeno "Brasil" e da expressão da "brasilidade" vindas a lume no decurso dessa luta corpo a corpo de Alexandra Lucas Coelho com o universo brasileiro e com as versões oficiais da historiografia colonial portuguesa são reflexo da necessidade de combinar a revolução modernista com exemplos pragmáticos sobre o que constitui um modo de imersão contemporânea nos assuntos tipicamente brasileiros. Organizado numa forma barroca que tira partido de uma perspetiva de simultaneidade histórica, Deus-dará oferecenos uma visão do apocalipse brasileiro por meio da redescrição do encontro de Portugal com o Brasil. É como reencenação crucial do encontro de quinhentos anos entre os índios e os portugueses que o livro procura capitalizar todo o conhecimento e a experiência direta que Alexandra tem do Brasil.

Talvez isso explique que por vezes o livro se pareça com uma coleção de ilustrações sobre ideias gerais. Numa sequência de substituições geográficas sucessivas, de tonalidade muito contemporânea, os crimes, o 
sofrimento e a humilhação provocados pela expansão colonial são perspectivados horizontalmente em relação aos crimes cometidos ainda hoje em relação às populações das periferias do Brasil e estes, numa abertura panorâmica muito do agrado da autora, perspectivados horizontalmente em relação aos crimes ambientais perpetrados na Amazônia.

E é também num sentido coextensivo dessa analogia que $A$ nossa alegria chegou pode ser considerado um "romance brasileiro": o que se passa em Alendabar é obviamente uma alegoria da situação do Sul Global no Antropoceno, mas, ao mesmo tempo, as realidades evocadas estão obviamente disponíveis para se articularem numa significação concretamente brasileira. Não faltará certamente quem jure a pés juntos, e com inteira razão para isso, que Alendabar é inconfundivelmente o Brasil só que com outro nome. As vidas exemplares das suas personagens, intervindo com sutileza e elegância numa história comum, apelam diretamente à ação e encarnam a esperança na revolução que redesenhe os mapas jurídicos dos impérios, e, num equinócio simbólico, permita que as duas partes do mundo sejam iluminadas por igual.

Todavia, reconheço algo insípido nesta tentativa de revisão neorromântica dos valores correntes. O indianismo invertido e ambivalente de Mário de Andrade, tão patente nos tropos e nas palavras de Deus-dará, pouco influi na atmosfera emocional de A nossa alegria chegou, fábula idílicopastoral de um eco-utopismo corrente. Em lugar de uma energia vital modulada pela absorção da diferença e pela inconstância da alma, o lídimo regime pedagógico de $A$ nossa alegria chegou exprime-se, em muitos momentos, nos termos de uma consciência arcádica new age, abnegada e politicamente correta, sem dúvida, mas também solipsista perante as crises globais.

Nesse plano, a dinâmica essencial de A nossa alegria chegou - nesta ordem de ideias posterior a Deus-dará apenas porque foi escrito depois aproxima-se mais do epos indianista de Alencar do que da carnavalização dos modernistas, e por isso talvez se possa acrescentar a sugestão de que $A$ nossa alegria chegou está para Deus-dará como Iracema está para o Macunaíma. Um prolonga-se no outro, pelos mesmos motivos orgânicos que Mário de Andrade prolonga a tupinização gramatical de José de Alencar, da mesma maneira que Alencar prolonga o trilho nativista desbravado pelos inconfidentes de Minas Gerais. Quer dizer: do ponto de vista da narrativa da formação da literatura brasileira, para falar com Candido, esses autores consideram que a forma pós-colonial do Brasil traduz o culminar de um 
percurso histórico cuja unidade "é ao mesmo tempo memória e exclusão da árvore de onde proveio" (BAPTISTA, 2005, p. 67).

Tanto Mário como Alencar presunçosamente sugeriram que poderíamos sublimar o dilema pós-colonial imaginando uma adequação do comportamento linguístico da comunidade ao mundo que se habita. Assim, quando tradicionalizam os sentimentos nativistas que a "comédia ideológica" da sociedade local (SCHWARZ, 2007, p. 12) e a presença enraizada da cultura europeia traziam ainda muito porosos, os românticos e os modernistas mais não estão do que a traduzir as suas metáforas nativistas numa língua tupinizada que os ajude a opor os naturais do Brasil aos naturais de outro lugar qualquer. O Brasil de Deus-dará e A nossa alegria chegou, conforme com os seus antecessores, vangloria-se de ombrear com um mundo aventuroso que está sempre em estado de aurora, mesmo que as jandaias, cantando "ainda no olho do coqueiro", não repitam já "o mavioso nome de Iracema”. Como qualquer outra lei inelutável, essa acaba por se tornar mais uma forma voluntária de cativeiro. Percebe-se, assim, que em 1942, na célebre conferência em que meditou sobre as realizações da geração modernista, Mário de Andrade se tenha censurado pelo fato de tanto ele como os companheiros terem perdido de vista o povo de que tanto falavam e se terem focado apenas neles mesmos.

Tentando mostrar como é que um romance português em Portugal pode tornar-se um romance brasileiro no Brasil, Deus-dará viu-se fatalmente subordinado às Escrituras Modernistas, que ainda hoje reclamam o monopólio da fundação moderna da identidade brasileira que o romantismo não fora capaz de autonomizar integralmente. Comparativamente, o machadiano Vai, Brasil, anterior, por assim dizer, a essa interiorização formal do Macunaíma, nomeadamente em termos de linguagem, não sofreu ainda o impacto restritivo do transe antropófago. Em vez disso, é "meramente" a crônica de viagem de uma repórter talentosa e muito experiente, que não esconde a visão problematizadora das dificuldades e das assimetrias locais sob a semântica reconciliadora de um indianismo mítico, e que tem a consciência aguda de estar a observar e a ouvir os vencidos do Brasil quando se depara com os habitantes crepusculares da grande floresta. Por mais paradoxal que isso possa parecer, recorrendo a passagens de Bosi e de Schwarz, posso aproximar Vai, Brasil de Machado de Assis constatando, que, tal como o Bruxo, Lucas Coelho não se entrega à "febre da descrição plástica e vívida dos ambientes em que se movem as suas personagens" (BOSI, 2018, p. 200), e argumentando que as suas crónicas resultam de um 
dispositivo formal que parte das contingências locais para encontrar significados mais abrangentes (SCHWARZ, 1990, p. 151).

Talvez pelo fato de enformar o estádio inicial da descoberta do Brasil por uma jornalista portuguesa e ser esboçado na "arte pobre" e antológica da crônica da imprensa, Vai, Brasil, especialmente nas crônicas sobre a vida amazônica, empenha-se na tarefa de observar o Brasil através do rastro da desolação, do desamparo e da insustentabilidade deixados pela presença ocidental. Posto em paralelo com Vai, Brasil, Deus-dará (ainda quando evoca o perspectivismo ameríndio de Viveiros de Castro) não deixa de estar perfeitamente alinhado com os sarcasmos epistemológicos típicos de Macunaima e Serafim Ponte Grande.

Comparada com a Amazônia modernista de Deus-dará, que leva os protagonistas a participarem num ritual xamânico na Serra dos Órgãos, a Amazônia de Vai, Brasil parece aproximar-se mais do lamento antropológico de Tristes trópicos (STEINER, 2010, p. 308). Diante das portas da floresta, diante da treva do "emaranhado verde, compacto" em que as cidades flutuavam incandescentes (COELHO, 2013, p. 90), Lucas Coelho vai se descobrir "mais portuguesa" do que antes. Se se descobre mais portuguesa do que antes, numa compulsão pela mudança de perspectiva, talvez isso suceda porque a noção cosmológica de que pode devir portuguesa, índio e onça alternativamente a torna mais aberta para a tensão da alteridade. Ao passo que Deus-dará recapitula com certa complacência a imagem que o Brasil tem de si mesmo, Vai, Brasil critica de forma sistemática as consequências devastadoras da exaltação europeia sob o mundo primitivo das Américas. Por vezes, pede um leitor especial, mas, talvez como nenhum dos outros livros de Alexandra, ajuda-nos a responder a perguntas sobre o futuro da Terra, que, mais do que nunca, está a assumir-se como palco não do confronto político entre o centro e a margem, mas do confronto ecológico entre a cidade, cada vez mais consensualmente usurária, e a floresta, tragicamente cada vez mais exausta.

Em resumo, o que da maneira mais simples nos permite distinguir os dois extremos da série, Vai, Brasil e Deus-dará, é o fato de o primeiro, ao contrário do segundo, não solicitar uma identificação perfeita com o país tropical cuja idiossincrasia linguística Mário de Andrade se esforçou por representar, mas desenvolver uma bem machadiana visão problematizadora da realidade, a qual - considerando que um quarto do livro relata uma viagem prolongada à Amazônia - é estipulada a partir do ponto de vista das populações vencidas pela exploração colonial. Isto tem consequências claras 
na natureza dos dois livros. É que o espírito revolucionário modernista, tomado pelo que efetivamente foi, não pelo que quis ser, não traduziu o começo de nada, mas, como o próprio Mário de Andrade de "Meditação sobre o Tietê" amargamente acabou por admitir, se entregou ao estertor autoindulgente com que os "filhos finais de uma civilização que se acabou" (ANDRADE, 1974, p. 76) se celebram demagogicamente a eles mesmos. Esta distinção é aliás prolongada nos títulos e nas páginas finais dos livros: se Deus-dará, plenamente engajado no folclore oswaldiano, nos garante que o Brasil será sempre uma alegoria de si próprio; Vai, Brasil, terminado com uma melancólica carta da autora ao poeta Caio Fernando Abreu, avisa-nos que as soluções modernistas não demoveram os velhos problemas do país.

Por não ser indianista nem modernista e, mais ainda, pelo fato do tom documental refrear a identificação com a bem-aventurança brasileira em prol da assunção das contingências, Vai, Brasil parece proporcionar-nos, em contracorrente com as ideias da autora, o livro mais ecocêntrico desta sequência de Lucas Coelho. Primeiro, porque as crônicas - um pouco à semelhança das raízes das opulentas árvores amazônicas, que se instalam luxuosamente em solos pobres e promovem políticas biológicas de reciclagem intensiva - se atrevem a observar o Brasil sem se devotarem como Deus-dará à torrente simbólica "intemporal e supergeográfica" (MARTINS, 2002, p. 206) encarnada por Macunaíma, que Iracema, mais modestamente, também já perseguira.

Mais ecocêntrico, ainda, porque o faz sem reclamar sentidos profundos ou uma plêiade de leituras complementares: só pede que os leitores considerem responsavelmente a ideia, nem sequer original, de que a história do mundo tem sido essencialmente uma história de como as pessoas se deparam com a necessidade de obter a todo o momento consensos a partir de modos de pensar e agir muito diferentes uns dos outros. E porque recomenda, como Machado de Assis, não um ajuste perfeito ao mundo em que se está, mas a curiosidade persistente pelo que tem permanecido na obscuridade. É verdade que Deus-dará é um hino aos chavões de Oswald de Andrade e um hino às críticas aos chavões lusotropicalistas de Gilberto Freyre, afinado com os apelos libertários das teses de Benjamin sobre a história. É verdade que está mais do que apto a representar energicamente o amor-próprio dos naturais de algum ponto entre o Oiapoque e o Chuí e a repudiar a violência colonial lusíada, enquanto pisca um olho cúmplice tanto aos brasilianistas como aos sociólogos pós-coloniais dos departamentos acadêmicos. É verdade também que $A$ nossa alegria chegou é uma apodítica 
defesa da liberdade de reescrever o mundo, perfeitamente apta a dar voz às grandes causas contemporâneas e, pelo menos em teoria, a esposar versões alternativas da história social - mais ambientalmente responsáveis porque mais democráticas.

A meu ver, o problema é que, como em qualquer outra narrativa escorada, ainda que inconscientemente, em tropos nacionalistas e em conflitos entre os povos e as culturas, ambos remetem para o conforto das coisas familiares nos termos de um país desenhado à medida do povo brasileiro. Ora, uma das coisas que Machado de Assis exemplificou com a sua indiferença magistral em relação ao problema do nacionalismo na tradição literária (que foi, como se sabe, o tópico maior das primeiras cartas trocadas entre Mário e Carlos Drummond de Andrade) é que o Brasil nunca está "simplesmente" diante de nós. Mais ainda, avisa-nos que o argumento modernista que baseia os laços sociais na posse de um território comum deverá ser substituído pela assunção da ambiguidade e da contingência das nossas crenças, pontos de vista e atitudes perante os nossos companheiros.

Dizer que se impõe uma reflexão empenhada a respeito do cinismo etnocêntrico das democracias contemporâneas (que o Brasil contemporâneo ilustra com particular acuidade) equivale neste sentido a dizer que se impõe, entre outras coisas, uma reflexão machadiana sobre o modo como temos transmitido a todas as criaturas debaixo do sol o legado de nossa miséria. Talvez se possa dizer, embora ao preço de cometer certa injustiça para com as admiráveis qualidades de Deus-dará, que o telos de Vai, Brasil não é ainda o de Mário e de Oswald de Andrade, que pregam o direito incondicional à revolução estética e elevam Macunaíma a símbolo maior da resposta às falácias europeias - mas o bem-humorado, triste e irónico pessimismo de Joaquim Maria Machado de Assis, desconfiado da utilidade dos projetos metafísicos da nação face ao caráter pluralista e contingente da realidade. Nas epifanias amazônicas de Vai, Brasil, Lucas Coelho hipostasia a descrença de Machado num nacionalismo baseado em visões etnocêntricas verticais. Em Deus-dará, a alegria é a de Mário de Andrade: "Tudo está em gostar da vida e saber vivê-la. Só há um jeito feliz de viver a vida: é ter espírito religioso. [...] trata-se de ter espírito religioso pra com a vida, isto é, viver com religião a vida" (ANDRADE, 2002, p. 46). Em Vai, Brasil, a alegria é que decorre de compreender a afirmação de vida que os índios do Brasil ainda exemplificam no âmbito de modelos econômicos de raiz colonial, que anulam o sentido das idiossincrasias privadas numa metáfora a-historicista da unidade nacional. 
Resenhando em 1899 a $2^{\text {a }}$ edição de Cenas da vida amazônica (a primeira viera a lume treze anos antes, em Lisboa), do crítico literário e etnógrafo paraense José Veríssimo, Machado, desvalorizando de modo deliberado os ditames naturalistas, observou que o livro de Veríssimo constata que há claramente uma objeção mútua entre a floresta e o "homem":

O contraste é grande. A floresta e a água envolvem e acabrunham a alma. A magnificência daquelas regiões chega a ser excessiva. Tudo é inumerável e imensurável. São milhões, milhares e centenas os seres que vão pelos rios e igarapés, que espiam entre a água e a terra, ou bramam e cantam na mata, em meio de um concerto de rumores, cóleras, delícias e mistérios (ASSIS, 2013, p. 681).

A que acrescenta, pouco depois, uma alusão sombria sobre a natureza apocalíptica da marcha da civilização: "Mais tarde, algum crítico da escola do autor compulsará as suas páginas para restituir costumes extintos. Muito estará mudado. Onde José Tapuio lutou com a sicuriju até matá-la, outro homem estudará alguma nova força da natureza até reduzi-la ao doméstico”. Ora, mais de um século depois, enquanto somos bombardeados diariamente com a tragédia das alterações climáticas, Machado de Assis parece-nos anacronicamente contemporâneo. Para fins ecológicos, aliás, julgo que vale a pena aproveitar as sugestões chocantemente atuais dessa passagem para retomar a breve história ficcional com que comecei este ensaio, e pensarmos, mais uma vez, no modo como as questões ambientais e indígenas têm sido abordadas nas últimas décadas pelos responsáveis políticos brasileiros e como as diferentes modalidades de visões do Paraíso foram cristalizando em metáforas gastas as relações de vizinhança com a floresta amazônica.

$\mathrm{O}$ fato de Machado nunca ter abrasileirado a prosa com papagaios e sucuris parece tê-lo deixado livre para escapar às analogias fáceis entre o "homem e o meio" de que a propaganda nacionalista do Modernismo abundantemente se serviu para fins políticos. Assim, o que se deduz desse trecho invulgarmente sério do Bruxo do Cosme Velho - a oposição irrefutável que há entre a vida aborígene e a civilização brasileira - torna-se ainda mais crucial no tempo presente: a verdade é que pensar a floresta Amazônica faz-nos penosamente reconhecer que o que se fez em nome de "estados de espírito nacionais" manteve a insensibilidade colonial a pessoas, estilos de vida e tipos de sofrimento diferentes dos nossos.

Felizmente, hoje já dispomos de livros totalmente indiferentes às injunções da versão colonial de struggle for life posta em prática pela teoria 
modernista. Livros como Metafísicas canibais, de Eduardo Viveiros de Castro, e $A$ queda do céu, de Davi Kopenawa, para me ficar em dois casos célebres, já nos ajudam a abordar a terra-floresta e o mundo ameríndio de dentro para fora e não de fora para dentro. O mesmo é dizer, já nos ajudam a ver os índios, as jandaias e os coqueiros de Iracema em si mesmos, na floresta do seu meio natural. Sobretudo, ajudam-nos a ver os índios para lá da cerca mitopoética modernista, cujos sucessivos heróis "mestiços", "fracassados" e "cordiais" (MARTINS, 2002, p. 173-176), embora possam dizer coisas úteis sobre as cidades e fazendas do Nordeste ou do Sudeste, pouco contribuem para o estabelecimento de uma relação democrática entre os invasores e os povos da floresta. Lamentavelmente, a substituição do cerimonioso indianismo de Alencar por uma antropofagia sem cerimônias não corrigiu a má política anterior nem evitou que o pensamento selvagem continuasse a ser lido sob a perspectiva do caldeamento colonial.

Aliás, o que eu acho mais notável nesse passo é precisamente o modo como se instaura uma tensão de perspectivas que nos ajuda a compreender que a floresta não é somente o "fundo do mato-virgem" onde "nasceu Macunaíma, herói de nossa gente" - mas o lar de outros viventes, de outras pessoas. Pode ser até que a indiferença de Machado em relação ao nacionalismo congênito de Alencar, de Mário, de Oswald (que, no mesmo sentido que os famosos "narradores não confiáveis", denota o desejo do autor de experimentar constantemente pontos de vista distintos) funcione como um contraponto para a banalização da alteridade do ameríndio provocada pela autocomplacência que os escritores romântico-modernistas tipicamente votaram a si próprios.

Neste sentido, a extraordinária posteridade de Machado tem-nos demonstrado que poucos escritores se conhece que se adaptem tão bem como ele a meios adversos. Aos muitos exemplos com que Hélio Guimarães (2017), no livro mais completo de que dispomos sobre a história da recepção crítica de Machado de Assis, nos demonstra que a figura machadiana tem sobrevivido até mesmo nos loci mais contraintuitivos, eu acrescento o caso de uma série de crônicas portuguesas sobre a Amazônia do século XXI, em relação às quais sou tentado a conjecturar que, excetuando Viveiros de Castro e Davi Kopenawa, a influência decisiva parece ser, paradoxalmente, Machado de Assis, não Mário de Andrade \& Companhia.

Sem quebra da dignidade do estilo, quero por isso recomendar que o leitor dos livros de Machado experimente substituir a abordagem "sistêmica" de Candido, a solene abordagem "nacional", sempre preocupada com o que 
se foi e o que se virá a ser, por uma abordagem "ecossistêmica", "perspectivista", mais preocupada com aquilo em que nos tornamos. Sob estas condições, talvez seja possível reciclar alguns dos bons e velhos problemas machadianos e romântico-modernistas obtendo, digamos, benefício ambiental. Um intencionalista como Gledson e mesmo um marxista como Schwarz só engolindo sapos vivos concordariam com esse tipo de utilização tendenciosa do realismo de Brás Cubas. Nesse caso, remeto-os para as espirituosas linhas com que, na ressaca de um século de leituras, Hélio Guimarães, de sorriso matreiro, se pergunta se "em mais de cem anos de leituras incessantes da obra e de construção de diversas figuras de Machado de Assis, não terá sido principalmente ele, o escritor, que nos lê?" (GUIMARÃES, 2017, p. 280).

Onde Mário insistia em representar a existência brasileira como um estado de alma traduzível em notação musical (ANDRADE, 2002, p. 2002, p. 70), Machado - não contando com a irônica exceção das Americanas, que é fruto de constrangimentos sociais e literários específicos - retorquia que o Brasil não seria a paisagem representada pelos princípios autoevidentes do nacionalismo empenhado, interessado em sintetizar com abrangência e precisão as imagens harmoniosas da nação. Em vez da alegria religiosa de Mário sintonizada com o coração de todos os brasileiros, o Brasil de Machado é meramente a malha abertamente polifônica que está por trás das instituições públicas e dos modos privados de viver, da sua época e de todas as épocas, para os quais o pragmatismo moral de Brás Cubas de que "o modo de compensar uma janela fechada é abrir outra, afim de que a moral possa arejar continuamente a consciência" (ASSIS, 1962, p. 565) tem funcionado razoavelmente bem.

Enquanto não vem a lume Cinco voltas na Bahia e um beijo para Caetano Veloso, anunciado para breve, livro que, segundo a autora, completa a sua trilogia brasileira (pelo que eu passarei a partir daí a referir-me a uma tetralogia), a minha leitura das imagens do "Brasil" dos livros de Alexandra Lucas Coelho encontra-se em terrenos movediços. Portanto, termino limitando-me a defender que, no âmbito deste ensaio, é via Machado de Assis que Vai, Brasil se afasta do tipo de sensibilidade moral, histórica e literária encorajada pelos heróis romântico-modernistas do eixo Rio-São Paulo que cobre as palavras de Deus-dará e de A nossa alegria chegou com o manto a um tempo telúrico e situacionista do tropicalismo.

Para concluir: se me parece que a leitura dos livros de Machado de Assis intensificou o olhar de Alexandra Lucas Coelho sobre a ameaça 
apocalíptica que o Brasil vem enfrentando, é mais porque a inimitável capacidade de observação de Machado aconselha a troca periódica de vocabulário derivada da "lei da equivalência das janelas" do que por partilharem o alto sentido de responsabilidade modernista na racionalização, fundamentação e preservação dos traços genéricos do gênio brasileiro de Deus-dará, ou por profetizarem a alegoria redentora de $A$ nossa alegria chegou. De igual modo, é por alertar para a inconstância de qualquer ponto de vista sobre a verdade, ou sobre a justiça, ou sobre a moral que Vai, Brasil nos sensibiliza mais do que Deus-dará e $A$ nossa alegria chegou para a mensagem de que o Brasil não é apenas a "sociedade [antropocêntrica] fraterna, pluralista e sem preconceitos" consagrada pela Constituição que encarna com esplendor na roda de samba da Casa do Cosme Velho que fecha Deus-dará, mas é também essa incomensurável floresta - habitada por pessoas como árvores e animais, e por pessoas como negros e indígenas - que as realizações iluministas da Modernidade, prosaicamente, tantas vezes têm optado por esquecer.

\section{Referências}

ANDRADE, Mário de. O movimento Modernista. In: Aspectos da literatura brasileira. $5^{\text {a }}$ ed. Rio de Janeiro: Martins, 1974.

- Macunaíma: o herói sem nenhum caráter. Edição crítica de Telê Porto Ancona Lopez. Brasília: Coleção Arquivos, 1988.

ANDRADE, Mário de; ANDRADE, Carlos Drummond de. Carlos $\mathcal{E}$ Mário. Organização de Silviano Santiago. Rio de Janeiro: Editora Bem-Te-Vi, 2002.

ANDRADE, Oswald de. O manifesto antropófago. In: TELES, Gilberto Mendonça. Vanguarda europeia e modernismo brasileiro: apresentação e crítica dos principais manifestos vanguardistas. $3^{\mathrm{a}}$ ed. Petrópolis: Vozes, 1976.

ASSIS, Machado de. Memórias póstumas de Brás Cubas. In: Obra completa. 3 vols. Rio de Janeiro, Editora José Aguilar, 1962. v. 1, p. 509-637.

. Notícia da atual literatura brasileira. Instinto de Nacionalidade. In:

Crítica literária e textos diversos. Organização de Sílvia Maria Azevedo, Adriana Dusilek e Daniela Mantarro Callipo. São Paulo: Editora Unesp, 2013. p. 429-441.

. Cenas da vida amazônica, por José Veríssimo. In: Crítica literária e textos diversos. Organização de Sílvia Maria Azevedo, Adriana Dusilek e Daniela Mantarro Callipo. São Paulo: Editora Unesp, 2013. p. 679-684. 
BAPTISTA, Abel Barros. O cânone como formação: a teoria da literatura brasileira de Antonio Candido. In: o livro agreste. Campinas: Editora Unicamp, 2005. p. 41-80.

BOSI, Alfredo. Dialética da colonização. São Paulo: Companhia das Letras, 2002. . Brás Cubas em três versões. São Paulo: Companhia das Letras, 2006. . Augusto Meyer: crítica machadiana e memória. Estudos Avançados, São Paulo, n. 32 (92), 2018, p. 195-208.

CAMPOS, Haroldo. Iracema: uma arqueografia da vanguarda. In: Metalinguagem \& outras metas. São Paulo: Perspectiva, 1992.

COELHO, Alexandra Lucas. Vai, Brasil. Lisboa: Tinta da China, 2013. . Deus-dará. Lisboa: Tinta da China, 2016. . A nossa alegria chegou. Lisboa: Companhia das Letras, 2018.

CANDIDO, Antonio. Formação da literatura brasileira. $6^{\mathrm{a}}$ ed. Belo Horizonte: Itatiaia, 1981. v. 1 e 2.

GUIMARÃES, Hélio de Seixas. Machado de Assis, o escritor que nos lê: as figuras machadianas através da crítica e das polêmicas. São Paulo: Editora Unesp, 2017.

MARTINS, Wilson. A ideia modernista. Rio de Janeiro: Topbooks, 2002.

MERQUIOR, José Guilherme. De Anchieta a Euclides: breve história da literatura brasileira I. $3^{\mathrm{a}}$ ed. Rio de Janeiro: Topbooks, 1996.

RIBEIRO, Maria Aparecida. Dois rapsodos tropicais: Mário de Andrade e José de Alencar. Humanitas, Coimbra, v. XLVII, p. 1003-1025, 1995.

SCHWARZ, Roberto. Um mestre na periferia do capitalismo: Machado de Assis. São Paulo: Duas Cidades, 1990.

Ao vencedor as batatas. $5^{\mathrm{a}} \mathrm{ed} .3^{\mathrm{a}}$ reimp. São Paulo: Duas Cidades, 2007.

STEINER, George. O jardim perdido. In: George Steiner em The New Yorker. Organização de Robert Boyers. Lisboa: Gradiva, 2010. p. 298-308.

ANDRÉ CORRÊA DE SÁ é professor de literatura portuguesa e literaturas africanas de língua portuguesa na Universidade da Califórnia em Santa Barbara. Além de vários artigos sobre autores dos espaços luso-afro-brasileiros, é autor de Depressão e psicoterapia em António Lobo Antunes: qualquer coisa que me ajude a existir (Texto, 2019) e coorganizador de Mike Tyson para principiantes (Assírio \& Alvim, 2017). Atualmente, os seus interesses de pesquisa focam-se nas relações entre a literatura e o ambiente.

Dhttps://orcid.org/0000-0002-6468-745X E-mail: acorreadesa@ucsb.edu

Recebido: 18.09.2019

Aprovado: 10.01.2020 